\title{
The Adhesiveness of the PVD Coatings on Heat Treated Structural Steels
}

\author{
Stjepan GOLUBIĆ*, Ivica KLADARIĆ, Ivan SAMARDŽIĆ, Suzana JAKOVLJEVIĆ
}

\begin{abstract}
PVD coatings on hard materials reduce adhesion and abrasion wear, while some types of coatings also reduce friction. The temperature of the PVD process is lower than the tempering temperature of steels, so there is no deformed parts and no input of new stresses. During the heat treatment, the PVD process is performed at the end because the PVD coating does not require any subsequent heat treatment. This paper investigates the effect of applying PVD coatings (cVIc and nACVIc) on adhesiveness to three quenched and tempered structural steels (45S20, C45E and 42CrMo4). Prior to coating, all steels were heat-treated within the process of normalization, quenching and tempering, and were treated to four different surface roughnesses. Results obtained by measuring adhesiveness are statistically analyzed. Based on the experimental tests, it is determined that the adhesiveness of applied PVD coatings to quenched and tempered steels depends more on the type of coating and on previous heat treatment of the steel, and less on the type of steel and initial roughness.
\end{abstract}

Key words: adhesiveness; PVD (Physical Vapor Deposition) coatings; quenched and tempered structural steels

\section{INTRODUCTION}

Exploitation properties of machine parts and tools are usually improved by proper selection of materials. In addition to proper selection of materials, nowadays there is more attention given to development and usage of various heat treatment processes. Specific heat treatment processes are aimed at changing of properties, especially of surface layers, so that their service life under different wear conditions can be extended.

Surface engineering deals with such surface heat treatment processes. Basically, surface engineering procedures enable that properly prepared base material (substrate) gets subsequently treated with one of the surface technologies. The resulting properties of surface layer and base material cannot be achieved by using just one single material. Two basic groups of surface engineering procedures are modification and coating. Modification of the workpiece surface layer affects changes in its structure and properties, while coating creates a layer on the surface of the treated material [1].

One of the methods of surface coating is the physical coating in the vapor phase, or the Physical Vapor Deposition - PVD. This procedure creates a surface layer that differs in composition from the base material. Coating is formed by the transport of particles (atoms, molecules and ions) in a vacuum. Particles are physically transferred from the solid to the vapor phase. With the PVD process, it is possible to get thin coatings of almost all chemical elements. Chemical compounds, such as metal carbides, nitrides or oxides, can be also extracted by reactive process, which is of significance in modern technical applications. PVD coatings of hard materials reduce abrasion wear, and lowered friction factor also reduces adhesion wear [2-6]. In general, the PVD process provides good adhesion of the coating to the base material, thus making coating surfaces smooth and thin. The PVD process is performed in a final phase of the treatment because the PVD coating does not require any subsequent heat treatment. It is carried out at a temperature below 500 ${ }^{\circ} \mathrm{C}$, so that it is also suitable for steels being tempered at $\vartheta_{\mathrm{P}}$ $\geq 500{ }^{\circ} \mathrm{C}$ (e.g. high speed steel, hot work tool steels, quenched and tempered steels) [7].

Adhesiveness is defined as a state in which two surfaces are held together due to chemical bonds or mechanical connection between two different materials. Adhesiveness is one of the most important characteristics of a coating system. Properties of thin coatings (mechanical, electrical, optical) are weakened if coating adhesiveness is weak, i.e. if coating starts to peel off.

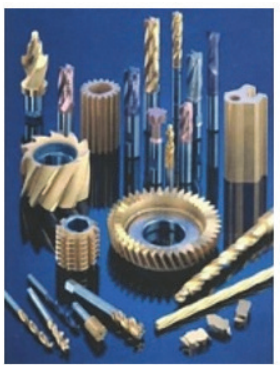

Cutting tools

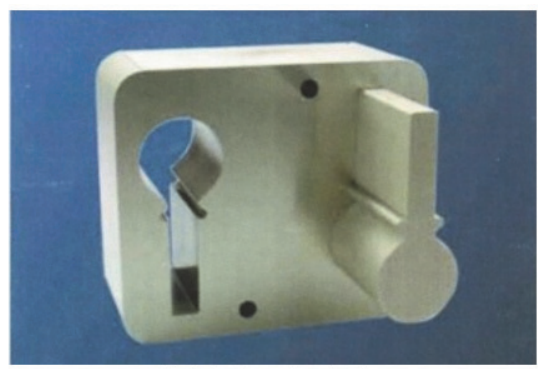

Metal stamping tools

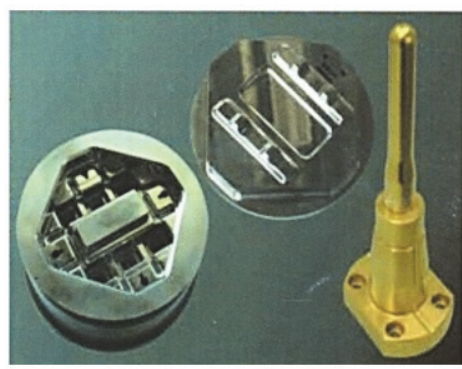

Injection molding tools

Figure 1 Examples of coatings on metal parts [9]

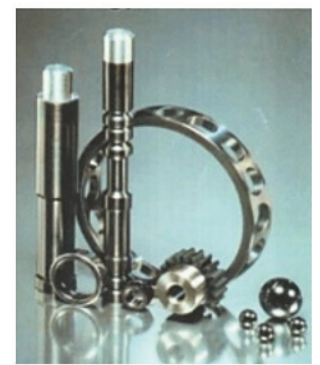

Machine elements
Base material surface cleanliness and roughness significantly affect the adhesiveness of coating. In addition to mechanical and chemical cleaning, vacuum procedures require the surface to be ionically cleaned before the coating is applied. Surface irregularities or defects improve adhesiveness because of mechanical connection between the base material and the coating. On the other hand, impurities and grain boundaries facilitate occurrence of 
porosity, which reduces the adhesiveness. Poor adhesiveness of hard coating causes cracks, blisters, and ultimately peeling of the coating [8]. Adhesiveness of coatings is usually measured by the scratch test or by the Rockwell indentation test for evaluation of adhesion.

The application of PVD coating is multiple: mechanical (tools, machine parts), automotive, military, textile industry (guides, needles), food industry (screw coils), wood industry (profile tools), in jewelry manufacture (knives, saws, molds), in chemical industry (protection against corrosion), in paper industry (knives, milling cutters, needles), in plastics processing (injection molding tools), in production of watches (decorative coatings), in medicine (surgical tools, prosthetics), as protective and decorative coatings on glass, ceramics, etc. Because of ecological awareness, PVD coatings are also used as an alternative for galvanic coating of cadmium, zinc, hard chromium, nickel, etc. [1]. Some examples of PVD coating of metal parts are shown in Fig. 1.

\section{EXPERIMENTAL PART}

Within the research into application of PVD coatings on structural steels, there are measurements performed to assess the effect of PVD coatings application on adhesiveness. Measurement of adhesiveness of coatings to the base material was carried out by using the Rockwell D method. Measurements were performed on three types of structural steels in normalized, quenched and tempered, and quenched state. After heat treatment, two groups of samples were coated with two types of PVD coatings (cVIc and nACVIc). Quenched and tempered structural steels used in this research are 45S20, C45E and 42CrMo4 steel. - The steel $45 \mathrm{~S} 20$ belongs to the group of structural steels used for processing on automatic machines. In particle separation process, it provides short fractured particles. It is applied in normalized or in quenched and tempered state.

- The steel C45E is a non-alloy steel with high carbon content. It is used in normalized, quenched and tempered state (surface tempering) for manufacture of mediumstrength machine parts.

- The steel 42CrMo4 is alloyed with chromium and molybdenum. It is applied in normalized, quenched and tempered state (surface tempering) for statically and dynamically loaded parts of vehicles, engines and machines.

Heat treatment parameters are selected according to the literature $[10,11]$ for heat treatment of quenched and tempered structural steels, as shown in Tab. 1.

Table 1 Selected parameters of heat treatment

\begin{tabular}{|c|c|c|c|c|c|c|c|c|c|c|c|}
\hline \multirow{2}{*}{ HT Steel } & \multicolumn{2}{|c|}{ Normalized / $N$} & \multicolumn{6}{|c|}{ Quenched and tempered / P } & \multicolumn{3}{|c|}{ Quenched / $K$} \\
\hline & $\vartheta_{\mathrm{N}} /{ }^{\circ} \mathrm{C}$ & $t / \mathrm{h}$ & $\vartheta_{\mathrm{a}} /{ }^{\circ} \mathrm{C}$ & $t / \mathrm{h}$ & tempering & $\vartheta_{\mathrm{p}} /{ }^{\circ} \mathrm{C}$ & $t / \mathrm{h}$ & cooling & $\vartheta_{\mathrm{a}} /{ }^{\circ} \mathrm{C}$ & $t / \mathrm{h}$ & tempering \\
\hline $45 \mathrm{~S} 20$ & 840 & 1 & 840 & 1 & water & 560 & 2 & air & 840 & 1 & water \\
\hline $\mathrm{C} 45 \mathrm{E}$ & 840 & 1 & 840 & 1 & water & 560 & 2 & air & 840 & 1 & water \\
\hline 42CrMo4 & 840 & 1 & 840 & 1 & oil & 560 & 2 & air & 840 & 1 & oil \\
\hline
\end{tabular}

Based on the requirements for selection of steel used in manufacture of machine parts (surface hardness, low friction factor, etc.), there are two types of PVD coatings selected for the experiment, namely the cVIc and nACVIc coating.

cVIc is a double coating with nanostructure being formed by a combination of $\mathrm{TiCN}+\mathrm{CBC}$ coating. The TiCN coating is a conventional coating with titanium, carbon and nitrogen elements, and the CBC (Carbon Based Coating) is a basic carbon coating. The $\mathrm{CBC}$ component is used as a dry lubricant with the purpose to reduce the friction factor.

nACVIc is a double coating with nanostructure being formed by a combination of $\mathrm{nACR}$ - $\mathrm{CBC}$ coating. The
nACRo(ncAlCrN/a-Si3N4) coating is a nanocomposite coating, and the $\mathrm{CBC}$ component is used as a dry lubricant with the purpose to reduce the friction factor. A titanium layer is applied to the nACVIc coating to improve connection with the base material.

The selected coatings are characterized by high hardness, low friction factor and thin coating thickness, and processing temperature is within the service area of quenched and tempered structural steels. Because of small coating thickness, correction of dimensional tolerance is not required on the existing structural parts. Tab. 2 overviews the basic properties of selected coatings.

Table 2 Properties of selected PVD coatings [9]

\begin{tabular}{|c|c|c|c|c|c|}
\hline \multicolumn{5}{|c|}{ Table 2 Properties of selected PVD coatings [9] } \\
\hline Coating & Color & Nanohardness / GPa & Thickness / $\mu \mathrm{m}$ & $\begin{array}{c}\text { Friction factor } \\
\text { (on steel) }\end{array}$ & Max. processing temperature / ${ }^{\circ} \mathrm{C}$ \\
\hline cVIc & gray & 25 & $1-2$ & 0,15 & 400 \\
\hline nACVIc & blue-gray & $40-25$ & $1-10$ & 0,15 & 450 \\
\hline
\end{tabular}

\subsection{Preparation of Samples}

There are 81 samples prepared for testing (three samples per each steel state, i.e. 27 samples without coating, and 54 samples with coating) in dimension of 10 $\times 10 \times 55 \mathrm{~mm}$ (Fig. 2). After heat treatment, longitudinal sheets $(10 \times 55 \mathrm{~mm})$ were tested to different surface roughnesses; $N_{3}(R a \leq 0,1 \mu \mathrm{m}), N_{4}(R a \leq 0,2 \mu \mathrm{m}), N_{5}(R a$ $\leq 0,4 \mu \mathrm{m})$ and $N_{6}(R a \leq 0,8 \mu \mathrm{m})$. The classes of roughnesses are marked at the sample fronts, and they are selected according to the roughnesses used in particle separation processing of metal in production of machine parts.

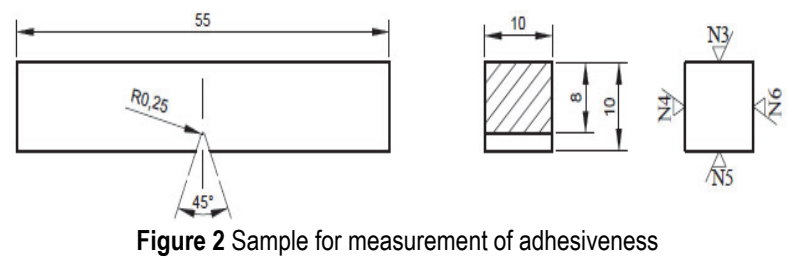




\subsection{Coating of Samples}

The coating of samples with PVD coatings was carried out in the Gazela-Platit company (Krško, Slovenia). The coating parameters were selected according to the types of coatings used in the Gazela-Platit company. For the cVIc coating, the process temperature was $450{ }^{\circ} \mathrm{C}$, and for the nACVIc coating, the process temperature was $460{ }^{\circ} \mathrm{C}$. The coating process for both cVIc and nACVIc lasted equally long. The first phase was 1 - hour-long warming up of the sample to the service temperature. Then, a 15 minute-long electronic cleaning was performed in the second phase. The third phase referred to the coating procedure that lasted for 3 hours. The transition from the solid into gaseous state was carried out by using an electric arc. Prior to the takeout, the samples were cooled in an oven for $1 \mathrm{~h}$ to a temperature of $100{ }^{\circ} \mathrm{C}$.

After coating, the thickness of the coating was measured by a cylindrical grinding method. Measured values are presented in Tab. 3 .

Table 3 Measured thickness of coatings after the coating process [12]

\begin{tabular}{|c|c|c|c|c|c|c|}
\hline \multirow{3}{*}{ Steel } & \multicolumn{6}{|c|}{ Coating thickness, $\mu \mathrm{m}$} \\
\hline & \multicolumn{2}{|c|}{ Normalized state / $N$} & \multicolumn{2}{|c|}{ Quenched and tempered state / $P$} & \multicolumn{2}{|c|}{ Quenched state / $K$} \\
\hline & $\mathrm{cVIc}$ & nACVIc & $\mathrm{cVIc}$ & nACVIc & cVIc & nACVIc \\
\hline $45 \mathrm{~S} 20$ & 1,79 & 2,64 & 1,68 & 2,84 & 2,10 & 2,68 \\
\hline $\mathrm{C} 45 \mathrm{E}$ & 2,09 & 2,59 & 1,65 & 2,52 & 1,70 & 2,75 \\
\hline 42CrMo4 & 1,73 & 2,82 & 1,89 & 2,55 & 1,58 & 2,60 \\
\hline
\end{tabular}

\subsection{Measuring of Adhesiveness}

Adhesiveness of coatings to the base material was measured by the Rockwell D, in accordance with the standard CEN/TS 1071-8: 2004 [10]. Hardness of sample base materials was less than $54 \mathrm{HRC}$, so there was a load of $981 \mathrm{~N}$ applied as of the mentioned standard. After loading, the samples were observed under a microscope with a magnification of $100: 1$. Three indentations were carried out for each material type, heat treatment and coating, as well as for each surface roughness condition. As of the mentioned standard, based on the imprint appearance, the coating adhesiveness is classified into four classes:

- class 0: no error,

- class 1: appearance of cracks, without peeling of coating,
- class 2: appearance of crack sand partial peeling of coating,

- class 3: complete peeling of coating.

Fig. 3 to Fig. 6 present the imprints as guidelines for classification in line with the standard CEN/TS 1071-8: 2004 [13].

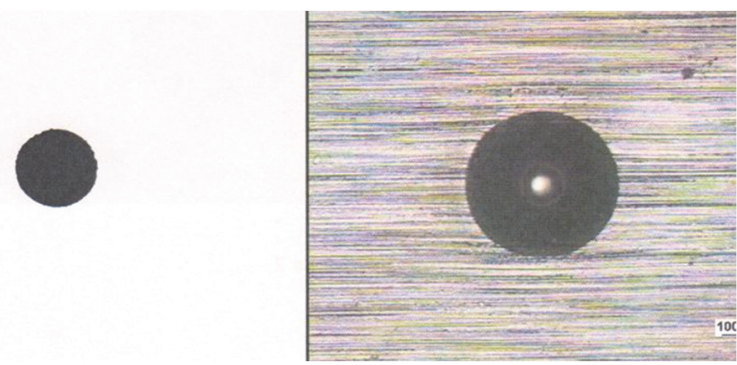

Figure 3 Classification of coating adhesiveness, class 0

Table 4 Determined classes of coating adhesiveness by the Rockwell Dindentation method [12]

\begin{tabular}{|c|c|c|c|c|c|c|c|c|c|c|c|}
\hline \multirow[b]{2}{*}{ Steel } & \multirow{2}{*}{ State } & \multirow{2}{*}{ Coating } & \multirow{2}{*}{ Sample } & \multicolumn{8}{|c|}{ Estimated class and mean adhesiveness values for initial roughness class } \\
\hline & & & & \multicolumn{2}{|c|}{$N_{3}$} & \multicolumn{2}{|l|}{$N_{4}$} & \multicolumn{2}{|l|}{$N_{5}$} & \multicolumn{2}{|l|}{$N_{6}$} \\
\hline \multirow{6}{*}{$45 \mathrm{~S} 20$} & \multirow{2}{*}{ Normalized } & cVIc & $14,15,16$ & $0 ; 0 ; 0$ & 0 & $0 ; 0 ; 0$ & 0 & $0 ; 0 ; 0$ & 0 & $0 ; 0 ; 0$ & 0 \\
\hline & & nACVIc & $17,18,19$ & $3 ; 3 ; 3$ & 3 & $3 ; 3 ; 3$ & 3 & $3 ; 1 ; 3$ & 3 & $3 ; 2 ; 1$ & 2 \\
\hline & \multirow{2}{*}{$\begin{array}{l}\text { Quenched } \\
\text { and tempered }\end{array}$} & $\mathrm{cVIc}$ & $24,25,26$ & $2 ; 2 ; 1$ & 2 & $1 ; 2 ; 2$ & 2 & $2 ; 2 ; 2 ;$ & 2 & $1 ; 2 ; 1$ & 1 \\
\hline & & nACVIc & $27,28,29$ & $2 ; 2 ; 3$ & 2 & $3 ; 3 ; 3$ & 3 & $3 ; 2 ; 3$ & 3 & $1 ; 2 ; 3$ & 2 \\
\hline & \multirow{2}{*}{ Quenched } & cVIc & $34,35,36$ & $2 ; 2 ; 2$ & 2 & $1 ; 1 ; 1$ & 1 & $1 ; 1 ; 1$ & 1 & $1 ; 2 ; 1$ & 1 \\
\hline & & nACVIc & $37,38,39$ & $3 ; 3 ; 3$ & 3 & $3 ; 3 ; 3$ & 3 & $3 ; 3 ; 3$ & 3 & $3 ; 3 ; 3$ & 3 \\
\hline \multirow{6}{*}{$\mathrm{C} 45 \mathrm{E}$} & \multirow{2}{*}{ Normalized } & $\mathrm{cVIc}$ & $44,45,46$ & $0 ; 1 ; 0$ & 0 & $0 ; 0 ; 0$ & 0 & $0 ; 0 ; 0$ & 0 & $0 ; 0 ; 0$ & 0 \\
\hline & & nACVIc & $47,48,49$ & $3 ; 1 ; 3$ & 3 & $3 ; 1 ; 3$ & 3 & $3 ; 1 ; 3$ & 3 & $3 ; 1 ; 2$ & 2 \\
\hline & \multirow{2}{*}{$\begin{array}{l}\text { Quenched } \\
\text { and tempered }\end{array}$} & cVIc & $54,55,56$ & $2 ; 1 ; 2$ & 2 & $1 ; 1 ; 1$ & 1 & $1 ; 2 ; 2$ & 2 & $1 ; 1 ; 2$ & 1 \\
\hline & & nACVIc & $57,58,59$ & $3 ; 3 ; 3$ & 3 & $3 ; 3 ; 3$ & 3 & $2 ; 3 ; 3$ & 3 & $3 ; 3 ; 2$ & 3 \\
\hline & \multirow{2}{*}{ Quenched } & cVIc & $64,65,66$ & $1 ; 1 ; 1$ & 1 & $2 ; 1 ; 1$ & 1 & $1 ; 2 ; 2$ & 2 & $2 ; 1 ; 2$ & 2 \\
\hline & & nACVIc & $67,68,69$ & $3 ; 3 ; 3$ & 3 & $3 ; 3 ; 3$ & 3 & $3 ; 3 ; 3$ & 3 & $3 ; 3 ; 2$ & 3 \\
\hline \multirow{6}{*}{$42 \mathrm{CrMo} 4$} & \multirow{2}{*}{ Normalized } & cVIc & $74,75,76$ & $1 ; 0 ; 0$ & 0 & $1 ; 0 ; 0$ & 0 & $1 ; 0 ; 0$ & 0 & $0 ; 0 ; 0$ & 0 \\
\hline & & nACVIc & $77,78,79$ & $2 ; 2 ; 3$ & 2 & $1 ; 2 ; 3$ & 2 & $2 ; 1 ; 3$ & 2 & $1 ; 1 ; 3$ & 2 \\
\hline & \multirow{2}{*}{$\begin{array}{c}\text { Quenched } \\
\text { and tempered }\end{array}$} & $\mathrm{cVIc}$ & $84,85,86$ & $2 ; 2 ; 1$ & 2 & $2 ; 2 ; 2$ & 2 & $1 ; 1 ; 2 ;$ & 1 & $1 ; 2 ; 1$ & 1 \\
\hline & & nACVIc & $87,88,89$ & $3 ; 3 ; 3$ & 3 & $3 ; 3 ; 3$ & 3 & $3 ; 3 ; 3$ & 3 & $3 ; 3 ; 3$ & 3 \\
\hline & \multirow{2}{*}{ Quenched } & cVIc & $94,95,96$ & $1 ; 2 ; 1$ & 1 & $1 ; 1 ; 1$ & 1 & $1 ; 1 ; 1$ & 1 & $1 ; 1 ; 1$ & 1 \\
\hline & & nACVIc & $97,98,99$ & $3 ; 3 ; 3$ & 3 & $3 ; 3 ; 3$ & 3 & $3 ; 3 ; 3$ & 3 & $3 ; 3 ; 3$ & 3 \\
\hline
\end{tabular}

The Rockwell D indentation test was performed in the Laboratory for materials of the Mechanical Engineering Faculty in Slavonski Brod, and the recording of imprint appearance is completed by a scanning electron microscope at the Faculty of Mechanical Engineering and
Naval Architecture in Zagreb. Tab. 4 presents the results of adhesiveness testing by the Rockwell $\mathrm{D}$ indentation method. Fig. 7 presents examples of imprint traces on the samples after examining the surfaces by the Rockwell D method for different steels, heat treatments and coatings. 


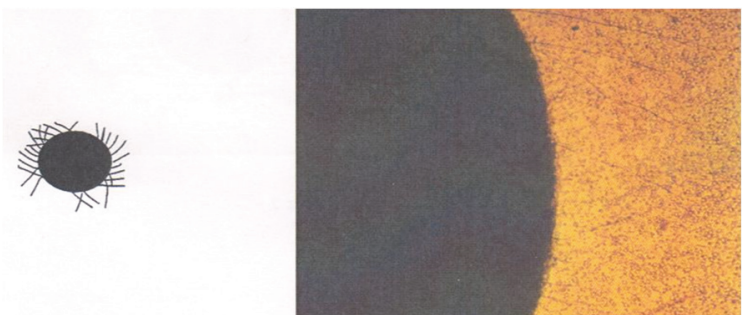

Figure 4 Classification of coating adhesiveness, class 1

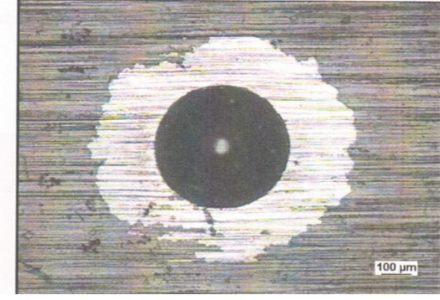

Figure 6 Classification of coating adhesiveness, class 3

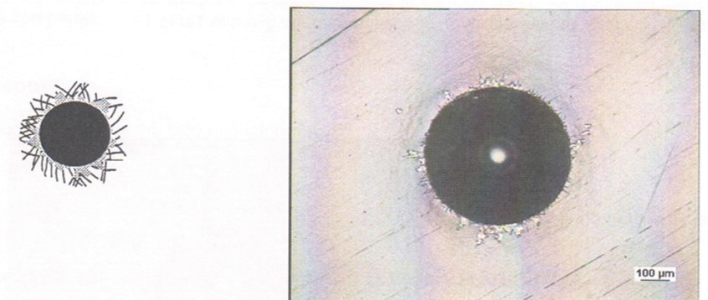

Figure 5 Classification of coating adhesiveness, class 2
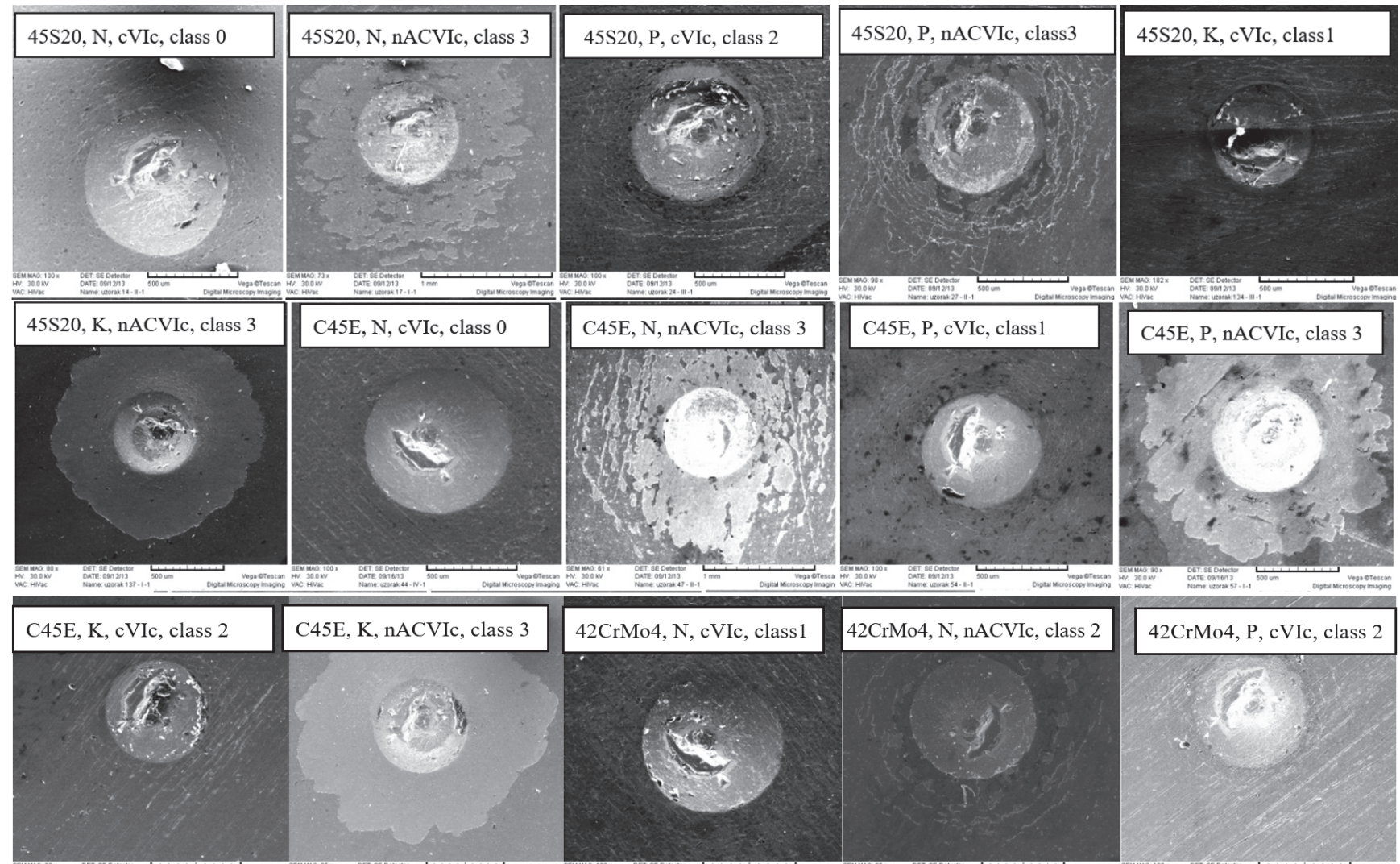

C45E, K, nACVIc, class 3

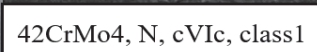

42CrMo4, N, nACVIc, class 2

42CrMo4, P, cVIc, class 2
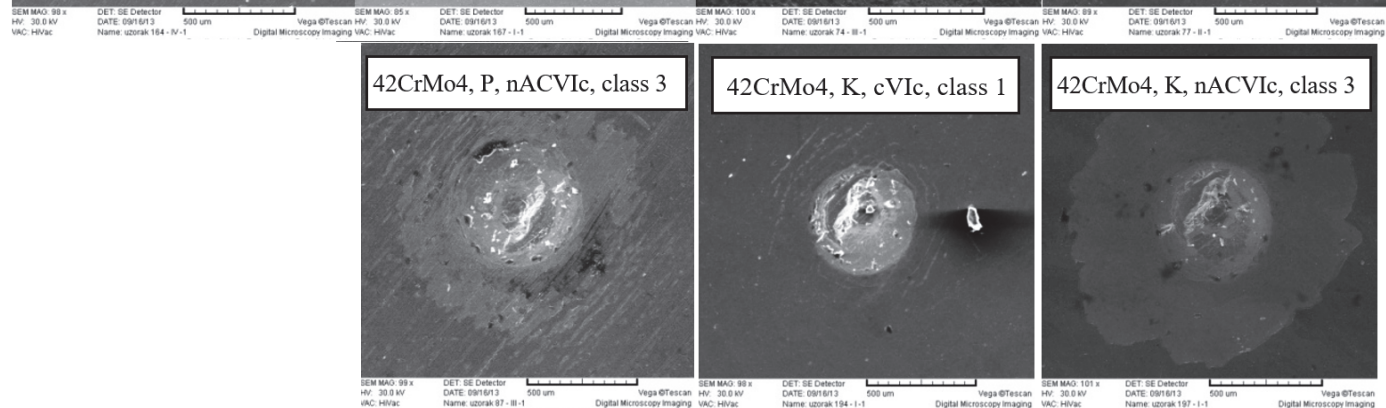

Figure 7 Appearance of imprints after adhesiveness testing, classified according to the type of steel, heat treatment, coating and adhesiveness class [12] (where is $N$ normalized state, $P$ quenched and tempered state and $K$ quenched state)

\section{DISCUSSION ABOUT ADHESIVENESS MEASUREMENT}

As presented in Tab. 4, it is proved that the steel 45S20 has the best adhesiveness in the normalized state when being coated with the cVIc coating, regardless of the initial surface roughness. Adhesiveness of the cVIc coatings for each condition of heat treatment is better than the adhesiveness of the nACVIc coatings. The steel $\mathrm{C} 45 \mathrm{E}$ exhibits better adhesiveness in the normalized state when being coated with the cVIc coating, regardless of the initial 
surface roughness. Adhesiveness of the cVIc coatings for each heat treatment condition is always better than the adhesiveness of the nACVIc coatings. The steel $42 \mathrm{CrMo} 4$ has the best adhesiveness in the normalized state when it is coated with the cVIc coating, regardless of the initial surface roughness. Adhesiveness of the cVIc coatings for each heat treatment condition is always better than adhesiveness of the nACVIc coatings.
Statistical analysis of the adhesiveness measurements is based on the mean value of adhesiveness on surfaces having different initial roughness, as stated by the data in Tab. 4.

Tab. 5 presents the results of the statistical analysis related to adhesiveness testing for all three steel types, three heat treatments, two types of coatings and four initial surface roughness.

Table 5 Statistical analysis results referring to adhesiveness testing

\begin{tabular}{|c|c|c|c|c|}
\hline \multirow[b]{2}{*}{ Source of variation } & \multicolumn{4}{|c|}{ Univariate significance test foradhesiveness } \\
\hline & Sum of the squared deviations, $S S$ & Degrees of freedom, $d f$ & $\begin{array}{c}\text { Corrected } \\
\text { variance, } M S\end{array}$ & $\begin{array}{l}\text { Calculated } F- \\
\text { test, } F_{\text {calc. }}\end{array}$ \\
\hline Constant & 249,3889 & 1 & 249,3889 & 1190,766 \\
\hline Steel & 0,4444 & 2 & 0,2222 & 1,061 \\
\hline Heat treatment & 13,5278 & 2 & 6,7639 & 32,296 \\
\hline Coating & 60,5000 & 1 & 60,5000 & 288,872 \\
\hline Class of roughness & 0,9444 & 3 & 0,3148 & 1,503 \\
\hline Error & 13,1944 & 63 & 0,2094 & \\
\hline
\end{tabular}

According to the statistical tables for the $F$ - test and $95 \%$ probability, for the degree of freedom $1 / 63$, limit value $F=3,99$; for the degree of freedom $2 / 63$ limit value $F=3,14$; and for the degree of freedom $3 / 63$ limit value $F$ $=2,75$.

After processing all results, comparison of the calculated value of the $F$ - test with the limit value showed that adhesiveness was affected by the heat treatment $\left(F_{\text {calc. }}\right.$ $=32,296)$ and by the type of coating $\left(F_{\text {calc. }}=288,872\right)$, while the type of steel $\left(F_{\text {calc. }}=1,061\right)$ and class of the initial roughness $\left(F_{\text {calc. }}=1,503\right)$ had no statistically significant effect on adhesiveness.

\section{CONCLUSION}

Adhesiveness of the PVD coating is influenced more by the type of coating and by the basic heat treatment, and less by the type of steel and initial roughness.

Regardless of previous heat treatment, the cVIc coating has better adhesiveness on all steels than the nACVIc coating. It is explained by the fact that chemical composition of the cVIc coating creates stronger chemical and mechanical bonds between the coating and the steel surface, which is not the case with the nACVIc coating. Steels coated with the cVIc coating in the normalized state have the best adhesiveness because of the structural state of the surface. Normalized structure, i.e. ferrite-pearlite structure is more prone to creating of stronger chemical and mechanical bonds with the cVIc coating than the quenched or tempered structures, i.e. martensitic structures. Significant increase in surface roughness before the application of the cVIc coating resulted in the improvement of adhesiveness to the base material because surface irregularities and defects improve adhesiveness due to the mechanical connection (anchoring) between coating and base material.

\section{REFERENCES}

[1] Gojić, M. (2010). Površinska obradba materijala, Sveučilište u Zagrebu, Sisak.

[2] Filetin, T. \& Grilec, K. (2004). Postupci modificiranja I prevlačenja površina, HDMT, Zagreb.
[3] Burakowski, T. \& Wierzchoń, T. (1999). Surface Engineering of Metals Principles, Equipment, Technologies, CRC Press, London (New York). https://doi.org/10.1201/9781420049923

[4] Lind, L., Adoberg, E., Aarik, L., Lulu, P., Veinthal, R., \& Aal, A. A. (2012). Tribological properties of PVD coatings with lubricating films. Estonian Journal of Engineering, 18(3), 193-201. https://doi.org/10.3176/eng.2012.3.04

[5] Polok-Rubiniec, M., Dobrzański, L. A., \& Adamiak M. (2007). Comparasion of the adhesion and wear resistance of the PVD coatings. Journal of Achievements in Materials and Manufacturing Engineering, 20(1-2), 87-90.

[6] Mrkvica, I., Neslušan, M., Čep, R., \& Sléha, V. (2016). Properties and comparasion of pvd coatings. Tehnick ivjesnik-Technical Gazette, 23(2), 569-574. https://doi.org/10.17559/TV-20140509105317

[7] Krumes, D. (2004). Površinsk etoplinske obrade I inženjerstvo površina. Strojarski fakultet u Slavonskom Brodu, Slavonski Brod.

[8] Panjan, P. \& Čekada, M. (2005). Zaščita orodij s trdimi PVD-prevlekami. Institut Jožef Stefan, Ljubljana.

[9] Gazela-Platit, catalog tvrdih prevlaka, interni catalog tvrtke Gazela d.o.o., Krško, Slovenia.

[10] Filetin, T., Kovačićek, F., \& Indof J. (2007). Svojstva I primjena materijala, Sveučilište u Zagrebu, Fakultet strojarstva I brodogradnje, Zagreb.

[11] Novosel, M. \& Krumes, D. (1995). Željezni materijali II. dio: Konstrukcijski čelici, Strojarski fakultet, Slavonski Brod.

[12] S. Golubić. (2018). Utjecaj nanošenja PVD prevlaka na svojstva konstrukcijskih čelika za poboljšavanje. Doctoral thesis, Strojarski fakultet u Slavonskom Brodu

[13] Advanced technical ceramics.Methods of test for ceramic coatings.Rockwell indentation test for evaluation of adhesion, D.D. CEN/TS 1071-8:2004 


\section{Contact information:}

Stjepan GOLUBIĆ, PhD

(Corresponding author)

Bjelovar University of Applied Sciences,

Trg E. Kvaternika 4, 43000 Bjelovar, Croatia

E-mail: sgolubic@vub.hr

Ivica KLADARIĆ, PhD, Full Professor

Mechanical Engineering Faculty in Slavonski Brod,

Sveučilište u Slavonskom Brodu,

Trg Stjepana Miletića 12, 35000 SlavonskiBrod, Croatia

E-mail: ikladaric@sfsb.hr

Ivan SAMARDŽlĆ, PhD, Full Professor

Mechanical Engineering Faculty in Slavonski Brod,

Sveučilište u Slavonskom Brodu,

Trg Stjepana Miletića 12, 35000 SlavonskiBrod, Croatia

E-mail: isamar@sfsb.hr

Suzana JAKOVLJEVIĆ, PhD, Associate Professor

Faculty of Mechanical Engineering and Naval Architecture,

University of Zagreb,

Ivana Lučića 5, 10000 Zagreb, Croatia

E-mail: suzana.jakovljevic@fsb.hr 